\title{
ANALISIS ANTIBAKTERI ALGA Padina australis HAUCK DI PERAIRAN TELUK TOTOK DAN PERAIRAN BLONGKO
}

\author{
(Antibacterial Analysis of Alga Padina australis Hauck in Totok Bay and Blongko \\ Waters)
}

\author{
Elsian S. Puasa ${ }^{{ }^{\star}}$, Desy M.H. Mantiri ${ }^{1}$, Antonius Rumengan ${ }^{1}$
}

1. Program Studi IImu Kelautan, Fakultas Perikanan dan IImu Kelautan, Universitas Sam Ratulangi, Manado

*e-mail: elsianpuasa@gmail.com

The purpose of this study is to determine the ability of antibacterial bioactivity in algae Padina australis Hauck collected from Totok Bay and Blongko waters. Algae P. australis Hauck is a macro-algae belonging to the brown algae (Phaeophyta), living attached to a hard substrate. The sampling location in Totok Bay, Southeast of Minahasa, is the estuary of the Totok River, where waste disposal proceeds from traditional gold processing and Blongko waters are relatively clean waters in South of Minahasa. The method used for antibacterial analysis is the method of resazurin. This method is oxidation reduction test. Resazurin indicator is blue color in oxidized condition will turn into pink. This method is used to determine the Minimum Barrier Concentration. Values obtained, analyzed with the Multiskan Go Spectrophotometer. The results showed that algae of $P$. australis Hauck from Totok buy waters had antibacterial activity against Gram positive bacterium Staphylococcus aureus at first well plate until well 3 with a barrier concentration value of MIC $1210.0 \mathrm{ppm}$. Similarly, algae from Totok Bay waters contain antibacterial activity in the gram negative bacteria Escherichia coli, on the first well plate with a barrier concentration value of $4840.0 \mathrm{ppm} / \mathrm{MIC}$. While on algae $P$. australis from Blongko waters did not found antibacterial compound.

Keywords : Padina australis, Hauck, antibacterial, Totok Bay, Blongko Waters

Tujuan penelitian ini adalah untuk mengetahui kemampuan bioaktivitas antibakteri pada alga Padina australis Hauck di Perairan Teluk Totok dan Perairan Blongko. Alga P. australis Hauck adalah makro alga yang termasuk dalam golongan alga coklat (Phaeophyta), hidup melekat pada substrat keras. Lokasi pertama pengambilan sampel yaitu Teluk Totok di Minahasa Tenggara merupakan muara dari sungai Totok, tempat buangan limbah hasil pengolahan emas. Lokasi kedua Perairan Blongko Minahasa Selatan merupakan perairan yang relative bersih. Metode yang digunakan untuk analisis antibakteri adalah metode resazurin. Metode ini adalah menguji oksidasi reduksi. Indikator resazurin, warna biru dalam kondisi teroksidasi akan berubah menjadi resofurin warna merah muda. Metode ini digunakan untuk menentukan Konsentrasi Hambatan Minimum. Nilai yang diperoleh, dianalisis melalui Spektofotometer Multiskan-Go. Hasil penelitian menunjukan bahwa alga $P$. australis Hauck dari Perairan Teluk Totok, mempunyai aktivitas antibakteri terhadap bakteri gram positif Staphylococcus aureus pada plate sumur pertama sampai sumur ketiga dengan nilai konsentrasi hambatan/MIC 1210,0 ppm. Demikian juga alga dari Perairan Teluk Totok terdapat aktivitas antibakteri pada bakteri gram negatif Escherichia coli, pada plate sumur pertama dengan nilai konsentrasi hambatan/MIC 4840,0 ppm. Sedangkan pada alga $P$. australis dari Perairan Blongko tidak ditemukan senyawa antibakteri.

Kata Kunci : Padina australis, Hauck, antibakteri, Teluk Totok, Perairan Blongko 


\section{PENDAHULUAN}

Indonesia merupakan negara bahari dengan keanekaragaman hayati laut terbesar di dunia. Laut beserta kawasan pesisir Indonesia dengan beragam biota yang hidup di dalamnya, mempunyai manfaat bagi manusia dan berpotensi ekonomi (pembangunan) yang sangat besar (Kusumastanto, 2011). Salah satu biota laut yang berpotensi sebagai bahan sediaan farmasitika dan ditemukan di Perairan Indonesia adalah makroalga atau dikenal dengan rumput laut. Sekitar 500 jenis alga telah teridentifikasi.

Sampai saat ini klasifikasi alga masih berdasarkan pigmen, seperti: Rhodophyceae (Alga merah), Chlorophyceae (Alga hijau), dan Phaeophyceae (Alga coklat) (Romimohtarto, dan Juana, 1999). Di antara alga tersebut, alga coklat selain dapat dimakan, merupakan salah satu sumber senyawa bioaktif karena mampu memproduksi metabolit sekunder yang bervariasi dengan aktivitas biologi yang luas. Sargassum polycystum (C. Agardh) mengandung beragam jenis pigmen, dan mempunyai aktivitas antibakteri, (Paraeng dkk, 2016; Kemer $d k k$, 2015). Sargassum polycytum (C. Agardh) dari Perairan Rap-rap mengandung klorofil dan karotenoid, serta berpotensi sebagai pewarna alami, pigmen karotenoid itu sendiri berfungsi sebagai pencegah kanker (Mantiri dan Kepel, 1999); Paransa $d k k$, 2014).

Alga Caulerpa serrulata dan Halimeda macroloba yang diambil dari Perairan Teluk Totok memiliki potensi untuk dapat digunakan sebagai fitoremediator logam seperti merkuri (Siahaan $d k k, 2015)$.

Alga Padina australis memiliki potensi sebagai bahan kosmetik (Kalalo, dkk, 2014). Sebagian besar makroalga hidup di perairan laut, memerlukan substrat sebagai tempat menempel/hidup. Substrat tersebut seperti batu, batu berpasir, tanah berpasir, kayu, cangkang moluska, dan alga yang hidup menempel pada tumbuhan lain atau jenis makroala jenis yang lain (Kepel dkk, 2001), dengan demikian alga tersebut harus mempertahankan hidupnya dengan memproduksi senyawa bioaktif. Alga Coklat $P$. australis Hauck memiliki manfaat bagi manusia sehingga perlu dilakukan penelitian tentang aktivitas antibakteri. Penelitian ini bertujuan untuk mengetahui kemampuan bioaktivitas antibakteri pada alga Padina australis Hauck di Perairan Teluk Totok dan Perairan Blongko dengan metode Resazurin.

\section{METODE PENELITIAN}

Aktivitas antibakteri pada penelitian ini menggunakan metode Resazurin. Resazurin merupakan senyawa aktif dari alamar biru yang diketahui merupakan indikator reaksi, reduksi, oksidasi (redoks) yang digunakan untuk menilai fungsi metabolisme sel. Pengamatan antibakteri jika perubahan warna dari biru (resazurin) menjadi warna pink (resorufiin) merupakan indikator terjadinya reduksi oleh sel.

Pengambilan sampel dilakukan dengan 'metode jelajah' yaitu menjelajahi Perairan Teluk Totok dan Perairan Pantai Blongko. Alga yang diambil adalah jenis alga coklat yang dominan di lokasi penelitian dan merupakan jenis yang sama yang terdapat di Perairan Teluk Totok dan Perairan Blongko. Alga yang ditemukan pada dua lokasi tersebut, setelah diidentifikasi adalah P. Australis, Hauck (Trono dan Ganzon Fortes, 1988).

Sampel alga yang ditemukan diambil dengan cara mencabut dari substrat tempat alga coklat tersebut menempel, tanpa memperhatikan tingkat pertumbuhan dari alga coklat tersebut. Alga yang sudah diambil dimasukan ke dalam plastik sampel yang telah diberi label dan dimasukkan ke dalam cool box. Selanjutnya sampel tersebut dibawa ke Laboratorium 
Biologi Molekuler dan Farmasitika Kelautan Fakultas Perikanan dan IImu kelautan Universitas Sam Ratulangi. Alga dibersihkan dengan air mengalir. Setelah dibersihkan sampel alga dikering anginkan kemudian ditimbang sebanyak $500 \mathrm{~g}$, dan dimasukan ke dalam botol yang sudah diberi label. Selanjutnya sampel alga diisi dengan metanol p.a sampai alganya tenggelam kemudian dimaserasi selama 24 jam. untuk dievaporasi. Analisis antioksidan dan antibakteri dengan metode resazurin dilakukan di Laboratorium Balai Besar Riset Pengolahan Produk dan Bioteknologi Kelautan (BBRP2BK) Jakarta.

\section{Prosedur Analisis Antibakteri}

Alat dan bahan yang akan dipakai dalam penelitian seperti erlemeyer, botol kecil, plate, pipet tips, Natrium klorida (NaCl), Nutrient Broth (NB), terlebih dahulu disterilkan menggunakan autoklaf pada suhu $121^{\circ} \mathrm{C}$ selama 150 menit.

\section{Proses Analisis Antibakteri Menggunakan Metode Resazurin}

Pembuatan Larutan $\mathrm{NaCl}$ yaitu Larutkan $\mathrm{NaCl}$ dalam $100 \mathrm{ml}$ air diaduk. Kemudian $\mathrm{NaCl} 9 \mathrm{ml}$ diisi kedalam 2 botol kosong yang sudah disediakan $(\mathrm{NaCl}$ untuk pengeceran bakteri $8,5 \%$ ) dan disterilkan dengan autoklaf.

\section{Pembuatan Media NB/Penumbuh Bakteri}

Timbang Nutrient Broth (NB) sebanyak 1,5 gram dan dituang ke dalam beker glass yang telah berisi air sebanyak $100 \mathrm{ml}$ lalu diaduk. Setelah tercampur, dituang ke dalam 4 botol sedang. Bakteri Escherichia coli dan Staphylococcus aureus kemudian diinokulasi dengan alat ESCO. Desinfektan disemprotkan pada permukaan kabin dengan alkohol $100 \%$. 4 botol NB/media penumbuh agar yang sudah di sterilkan, Bakteri $E$. coli dan Bakteri $S$. aureus yang ada di dalam erlemeyer juga disemprotkan terlebih dahulu dengan desinfektan sebelum dimasukan ke dalam ESCO. Bakteri $S$. aureus dengan menggunakan mikropipet $1000 \mathrm{ml}$ sebanyak $1 \mathrm{ml}$ kemudian diisi ke dalam 2 botol NB, begitu juga dengan bakteri E. coli diambil dengan mikropipet 1000 $\mathrm{ml}$ sebanyak $1 \mathrm{ml}$ lalu diisi ke dalam dua botol NB yang lain. Setelah itu ditutup kemudian di keluarkan 2 botol NB yang berisi bakteri $S$. aureus dan 2 botol NB yang berisi bakteri $E$. coli kemudian diberi label dan diletakan ke dalam pendingin dengan suhu $20^{\circ} \mathrm{C}$ dan ditunggu masa pertumbuhannya selama 24 jam.

\section{Persiapan Sampel}

Sampel dikeringkan menggunakan Freezedryer. Delapan tube disiapkan untuk dua sampel yang telah diberi kode, kemudian ditimbang berat kosong tube dan berat sampel (sampel diambil menggunakan mikropipet sebanyak $1 \mathrm{ml}$ ). Setelah itu di keringkan dengan alat Freezedryer. Kemudian 8 tube yang berisi sampel tersebut dimasukan kedalam alat Freezedryer untuk di vakum/dikeringkan. Setelah kering, sampel ditimbang lalu dilarutkan dengan metanol $1500 \mathrm{ml}+\mathrm{NaCl} 500$ $\mathrm{ml}$, kemudian dikocok sampai sampel larut untuk digunakan dalam uji antibakteri. Resazurin ditimbang sebanyak $3 \mathrm{mg} / 300 \mathrm{ml}$ lalu dimasukan ke dalam tube. Timbang berat tube yang berisi kloramfenikol dan tube kosong kemudian dikurangi.

\section{Prosedur Kerja Antibakteri}

Dua plate yang telah diberi kode disiapkan untuk uji antibakteri $S$. aureus dan $E$. coli. $\mathrm{NaCl}$ diisi ke semua sumuran yang ada di plate sebanyak $50 \mu \mathrm{l}$ kecuali sumuran pertama dikosongkan untuk diisi sampel sebanyak $100 \mu \mathrm{l}$. Keenam sampel tersebut diisi masing-masing ke dalam plate 96 sumuran pertama sebanyak $100 \mu \mathrm{l}$ menggunakan mikropipet. 
Sampel sumuran pertama diambil dengan mikropipet sebayak $50 \mu \mathrm{l}$ kemudian diisi ke baris selanjutnya, dilakukan dilusi menggunakan. Kemudian diisi dengan NB sebanyak $30 \mu \mathrm{l}$ ke semua sampel kecuali sumuran pertama. Bakteri $E$. coli dimasukan kesemua plate kecuali sumuran pertama sebanyak $10 \mu$ l. Selanjutnya resazurin sebanyak $10 \mu \mathrm{l}$ dimasukan ke semua plate kecuali sumuran pertama. Kontrol (-) diisi $\mathrm{NaCl}$ $50 \mu \mathrm{l}$, NB30 $\mu \mathrm{l}$, bakteri $10 \mathrm{ul}$, resazurin $10 \mu \mathrm{l}$. Kontrol (+) diisi kloramfenikol 50 $\mu \mathrm{l}, \mathrm{NaCl} 50 \mu \mathrm{l}$, NB $30 \mu \mathrm{l}$, Bakteri E.C 10 $\mu \mathrm{l}$, dan Resazurin $10 \mu \mathrm{l}$ (kosentrasi 10.000 diecerkan dari kosentrasi 100.000). $\mathrm{M}: \mathrm{NaCl}+\mathrm{MeOH}$. D : DMSO (Dimethyl Sulfoxide)10\%. Perubahan warna pada ekstrak menunjukan ada tidaknya aktivitas.

\section{HASIL DAN PEMBAHASAN}

\section{Hasil Analisis Antibakteri pada Alga Padina australis Hauck dari Teluk Totok dan Perairan Blongko}

Makro alga coklat $P$. australis hidup berkelompok dan tersebar di beberapa perairan di Sulawesi utara (Kepel $d k k$, 2001; 2015), termasuk alga yang mudah dilihat. Bentuknya seperti kipas, menempel pada substrat. Dalam proses pertumbuhannya, bagian thalus sering terkoyak. Thalusnya yang terdiri dari holdfast (seoerti akar), stipe (seperti batang), dan blade (seperti daun). Terdapat perbedaan warna alga $P$ australis. Di Perairan Teluk Totok, warnanya lebih kehijauan jika dibandingkan dengan alga yang ditemukan di Perairan Blongko seperti dilihat pada Gambar 1.

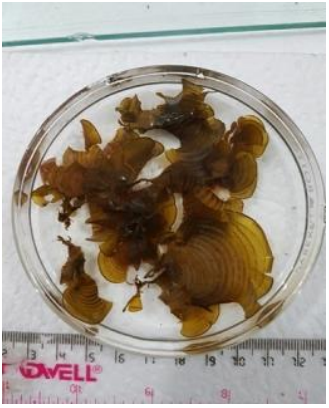

(a)

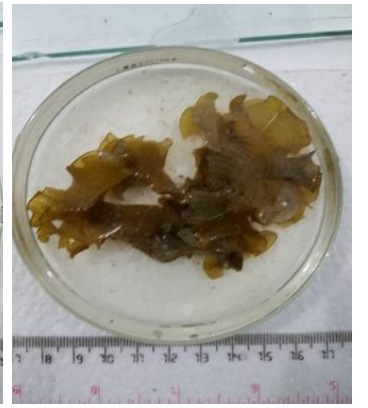

(b)
Gambar 1. (a) Alga Padina australis Hauck dari Perairan Teluk Totok, dan di (b) dari Perairan Blongko.

Hasil analisis antibakteri alga $P$. australis dari Perairan Teluk Totok dan Perairan Blongko terhadap bakteri $S$. aureus (gram positif) dan bakteri E. coli (gram negatif) yang dianalisis dengan alat Spektrofotometer Multiskan Go. Data diolah menggunakan perangkat lunak microsoft excel.

Kurva pada Gambar 2. menunjukan bahwa alga $P$. australis dari Perairan Teluk Totok mempunyai aktivitas anti bakteri terhadap bakteri $S$. aureus. Terlihat di sumuran pertama sampai sumuran ketiga, sedangkan pada sumur keempat sampai sumur kedua belas terjadi pertumbuhan/kepadatan bakteri sehingga mendapatkan nilai konsentrasi minimum penghambatan (Minimum inhibitotry concentration = MIC) $\mathrm{MIC}=1210,0 \mathrm{ppm}$ dan rerata $\mathrm{MIC}=1210,0 \mathrm{ppm}$.

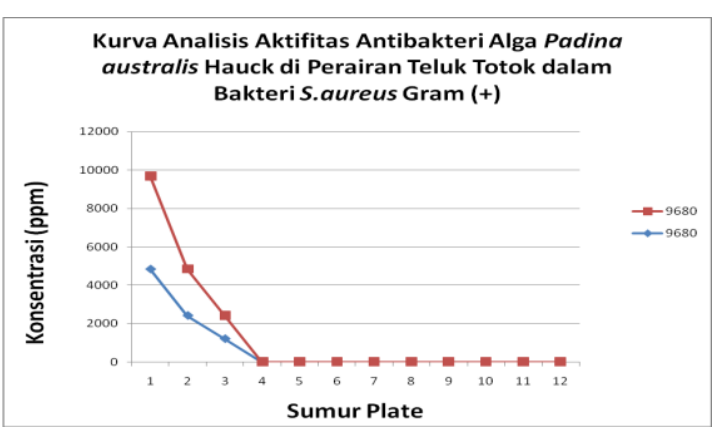

Gambar 2. Kurva aktivitas ekstrak $P$. australis dari Teluk Totok pada bakteri gram positif (S. aureus). 


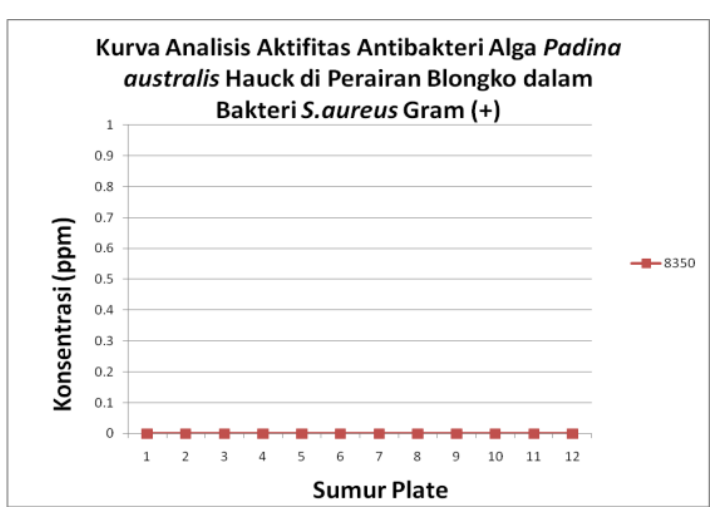

Gambar 3. Kurva aktivitas alga $P$. australis dari Perairan Blongko pada bakteri gram positif ( $S$. aureus).

Sedangkan pada Alga Padina australis dari Perairan Blongko terhadap bakteri $S$. aureus tidak mempunyai aktivitas antibakteri. Hal ini terlihat dari MIC = 0,0 ppm. Kurva Gambar 3. menunjukkan plate sumur pertama sampai dengan sumur dua belas tidak ada aktivitas.

Gambar 4. menunjukkan terjadi aktivitas pada Alga $P$. australis dari Perairan Teluk Totok terhadap bakteri gram negatif $E$. coli. Aktivitas ini hanya terjadi di sumur pertama, pada konsentrasi 4840 ppm. Sedangkan pada sumur ke dua dengan konsentrasi 2420 ppm sampai sumur kedua belas yang memiliki konsentrasi terendah terjadi pertumbuhan/kepadatan bakteri atau tidak memiliki aktivitas antibakteri. Nilai konsentrasi minimum penghambatan yang di peroleh adalah $\mathrm{MIC}=4840 \mathrm{ppm}$ dan rerata $\mathrm{MIC}=$ 4840 ppm. Jika di bandingkan dengan aktivitas antibakteri kontrol positif (cloramfenicol) yang memiliki nilai konsentrasi minimum penghambatan 2,4 ppm. Hal ini menunjukkan aktivitas antibakteri terhadap gram negatif dari sampel alga $P$. australis tidak begitu baik.

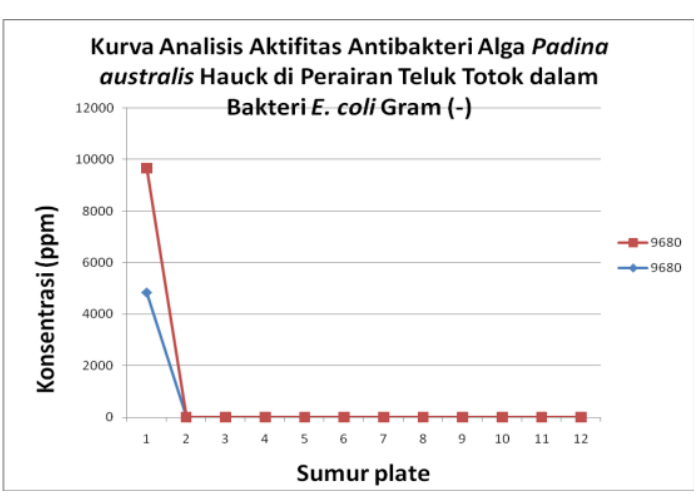

Gambar 4. Kurva aktivitas alga Padina australis dari perairan Teluk Totok pada bakteri gram negatif $(E$. coli).

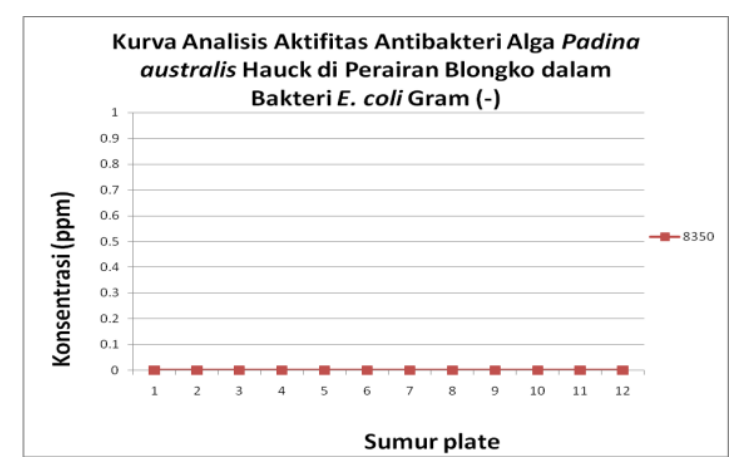

Gambar 5. Kurva tidak terjadi aktivitas alga $P$. australis dari Perairan Blongko pada Gram negatif ( $E$. coli).

Pada Alga Padina australis dari Perairan Blongko terhadap bakteri $E$. coli tidak terjadi aktivitas pada konsentrasi $8350 \mathrm{ppm}$. tapi terjadi pertumbuhan atau kepadatan bakteri seperti terlihat pada Gambar 5.

\section{Pembahasan Analisis Antibakteri dari Alga Padina australis Hauck dari Teluk Totok dan Perairan Blongko}

Perairan Teluk Totok terdapat banyak pertambangan emas skala kecil PESK), hasil limbah amalgamasinya hanya dibuang ke Sungai Totok dan bermuara ke laut, mengakibatkan air di perairan tersebut keruh dan relatif telah tercemar logam (Nasprianto, 2017). Hasil analisis menunjukan bahwa alga $P$. australis dari Perairan Teluk Totok mempunyai aktivitas antibakteri terhadap bakteri gram positif $S$. aureus dan alga ini juga 
mempunyai aktivitas antibakteri terhadap bakteri gram negatif $E$. coli. Sedangkan $P$. australis dari Perairan Blongko dimana perairan ini merupakan perairan yang relatif bersih, alga tidak mempunyai aktivitas antibakteri terhadap bakteri gram positif $S$. aureus dan terhadap bakteri gram negatif $E$. coli.

Alga yang hidup di perairan tercemar cenderung beradaptasi dengan lingkungannya seperti meningkatkan konsentrasi klorofil dan karotenoid (Nasprianto, 2017) seperti aktivitas lainnya seperti antibakteri.

Alga $P$. australis memiliki aktivitas antibakteri menggunakan metode Resazurin. Aktivitas antibakteri alga $P$. australis terhadap bakteri gram positif dan gram negatif hanya ditemukan perubahan warna pada kurang dari lima sumur. Perlu dilakukan perbandingan metode analisis antibakteri untuk spesies yang sama.

\section{KESIMPULAN}

Alga $P$. australis dari Perairan Teluk Totok dengan menggunakan metode resazurin mempunyai aktivitas antibakteri, terhadap bakteri gram positif $S$. aureus dan bakteri gram gram negatif E. coli. Sedangkan Alga $P$. australis dari Perairan Blongko tidak mempunyai aktivitas antibakteri terhadap.

\section{DAFTAR PUSTAKA}

Dawes, C.J. 1981., Marine Botany., John Wiley and Sons University of South Florida. New York.

Kalalo, J., Mantiri, D., Rimper J. 2014. Analisis Jenis-Jenis Pigmen Alga Coklat Padina australis Hauck dari Perairan Laut Sulawesi. Jurnal Pesisir dan Laut Tropis. 1: 8-12.

Kemer, K., Paransa, D.S.J., Rumengan, A.P., Mantiri, D.M.H. 2015. Antibakteri Dari
Beberapa Ekstrak Pada Alga Coklat. Jurnal LPPM Bidang Sains dan Teknologi. 2:73-81.

Kepel, R.C., Lumimgas, L.J.I., Pangau, F.N. 2001. Kepadatan Dan Pertumbuhan Alga Coklat Padina australis Hauck Di Perairan Desa Blongko, Minahasa. Jurnal Fakultas Perikanan Unsrat. 3:27-32.

Kepel, R.C., Mantiri, D.M.H., Manu, G.D. 2015. Pertumbuhan Alga Coklat Padina australis Hauch Di Perairan Pesisir, Desa Kampung Ambon, Kecamatan Likupang Timur, Kabupaten Minahasa Utara. Jurnal LPPM Bidang Sains dan Teknologi. 2:78-85.

Kusumastanto, $\quad$ T. 2011. Pengembangan Sumberdaya Kelautan dalam Memperkokoh Perokonomian Nasional Abad 21. Insitut Pertanian Bogor.

Nasprianto, 2017. Kandungan Logam, Struktur Sel, Pigmen Dan Antioksidan Pada Halimeda opuntia (Linnaeus) J.V. Lamouroux Dari Perairan Teluk Totok dan Perairan Blongko Sulawesi Utara. Skripsi. Fak. Perikanan Dan IImu Kelautan Unsrat.

Mantiri, D.M.H., Kepel, B.J. 1999. Beberapa Peranan Pigmen Karotenoid. Jurnal Fakultas Perikanan Unsrat. 1:139-147.

Muliro, S.P., Shalo, P.L., Kutima, P.M. 2013. Quality assessment of raw camel milk using dye reduction tests. African Journal of Food Science and Technology. 4:116-121.

Page, A.B., Page, A.M., Noel, C. 1993. A new fluorimetric assay for cytotoxicity measurements in vitro. Journal Oncol 3:473-476.

Paraeng, P., Mantiri, D.M.H., Rumengan, A. 2016. Uji 
Aktivitas Antioksidan Pada

Makro Alga Coklat

Hydroclathrus clathratus

(C.AGARDH) Hower Dan

Padina minor Yamada. Jurnal

Pesisir dan Laut Tropis. 2:37-

43.

Paransa, D.S.J., Kemer, K., Rumengan, A.P., Mantiri, D.M.H. 2014. Analisis Jenis Pigmen dan Uji Aktivitas Antibakteri Ekstrak Pigmen Xantofil Pada Alga Coklat Sargassum polyscytum (C.Agardh). Jurnal LPPM Bidang Sains dan Teknologi. 1:90-96.

Romimohtarto, K., Juwana. 1999. Biologi Laut. Puslitbang Oseanologi LIPI. Jakarta

Siahaan, D.O., Mantiri, D.M.H., Rumengan, A. 2015. Kajian Awal Fitoremediasi Merkuri Pada Caulerpa serrulata dan halimeda macroloba Dari Perairan Teluk Totok. Jurnal Pesisir dan Laut Tropis. 2:8-14.

Siahaan, B., Mantiri, D.M.H., Rimper J.R.T.S.L. 2017. Analisis Logam Timbal (Pb) Dan Kosentrasi Klorofil Pada Alga Padina australis Hauck Dari Perairan Teluk Totok dan Perairan Blongko, provinsi Sulawesi Utara. Jurnal Pesisir dan Laut Tropis. 2:31-37.

Trono Jr. G.C., Ganzon-Fortes. 1988. Phillippine Seaweds. National Book Store, Lnc. Phillippine

Yamaguchi H., Uchida K., Nagino K., Matsunaga T. 2002. Usefulness of a colorimetric method for testing antifungal drug susceptibilities of Aspergillus species to voriconazole. Journal Infect Chemother. 8:374-377. 